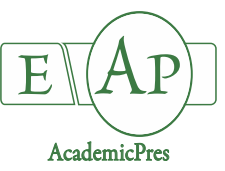

Rostami R et al. (2021)

Notulae Botanicae Horti Agrobotanici Cluj-Napoca

Volume 49, Issue 3, Article number 11924

DOI: $10.15835 /$ nbha49311924

Research Article

\title{
Growth, physiological, and biochemical responses of thyme (Thymus vulgaris L.) to the application of arbuscular mycorrhizal fungi under cadmium stress conditions
}

\author{
Roya ROSTAMI ${ }^{1}$, Seyed A. HOSSEINI ${ }^{1 *}$, \\ Behrooz ESMAIELPOUR ${ }^{2}$, Alireza ETMINAN ${ }^{3}$, Ghobad SALIMI ${ }^{3}$
}

\author{
${ }^{I}$ Department of Environment and Natural Resources, Kermanshah Branch, Islamic Azad University, Kermanshah, Iran; \\ Royarostami_206@yahoo.com;Asa_hosseini@yahoo.com (*corresponding author) \\ ${ }^{2}$ Mohaghegh Ardabili University, Department of Horticultural Science, Ardabil, Iran; behsmaiel@yahoo.com \\ ${ }^{3}$ Department of Plant Breeding and Biotechnology, Kermanshah Branch, Islamic Azad University, Kermanshah, Iran; \\ alietminan55@yahoo.com;salimi8m@yahoo.com
}

\begin{abstract}
Thyme (Thymus vulgaris L.) is one of the most important medicinal plants used in various pharmaceutical, osmotic, health, and food industries. Arbuscular mycorrhizal fungi (AMF) symbiosis is viewed as one of the several methods to improve growth under heavy metals stress. To investigate the effects of cadmium $(\mathrm{Cd})$ and AMF bio-fertilizers on the growth and morpho-physiological characteristics of thyme, a greenhouse experiment was performed in three replications. Experimental treatments included $\mathrm{Cd}$ at three levels 0,75 , and $150 \mathrm{mg} / \mathrm{kg}$ of soil and AMF at three levels without inoculation, inoculation with Funneliformis etunicatum, and Funneliformis mosseae. Cadmium stressed plant showed reduced plant height, number of leaves, stem fresh and dry weight, and root fresh and dry weight while AMF inoculation enhanced the increased means of these traits considerably. Inoculation with $F$. mosseae also ameliorated the Cd stress $(150 \mathrm{mg} / \mathrm{kg})$ induced reduction in plant height, number of leaves, and stem and root dry weight by $13.41 \%$, $8.42 \%, 30.3 \%$, and $22.2 \%$, respectively. Cadmium stress reduced membrane stability index while AMF inoculation enhanced membrane stability index considerably. An increase in soluble carbohydrate and proline content was observed due to Cd stress and AMF inoculation caused a further increase in these two metabolite contents ensuring better growth under $\mathrm{Cd}$ stressed conditions. Results indicated that $F$. mosseae had a higher efficiency in increasing morphological traits and improving physiological characteristics than $F$. etunicatum. Overall, AMF inoculation, especially $F$. mosseae significant ameliorative potential for Cd toxicity in thyme plants.
\end{abstract}

Keywords: antioxidant activity; bio-fertilizers; heavy metal toxicity; number of leaves; proline content

\section{Introduction}

Thyme (Thymus vulgaris L.), an aromatic perennial subshrub belonging to the Lamiaceae family, is commonly known for its therapeutic properties since ancient times. The whole plant and its various extracts 
are used in the medicine, cosmetic, and food industry. The genus Thymus is one of the important members of the Lamiaceae family and comprises more than 325 species worldwide (Kucukaydin et al., 2020). Among the thyme species, 18 species have been identified from Iran, three of which are called Iranian thyme, Danai thyme, and Marandi thyme are exclusive of Iran (Kalvandi et al., 2014; Pirbalouti et al., 2015). Thyme contains about 0.8 to $2.6 \%$ essential oil of dry matter, mostly phenols, monoterpene hydrocarbons, and alcohols.

Cadmium $(\mathrm{Cd})$ is included in the list of highly toxic environmental pollutants due to a considerable threat to all organisms, including plants and humans (Kabir et al., 2018). Cadmium is believed to accumulate in both water and soil due to phosphate fertilizers and industrial activities (Kaya et al., 2019). Song et al. (2016) reported that $\mathrm{Cd}$ contamination is one of the major environmental problems in the agricultural system due to its long stay in the soil for thousands of years. It has been reported that $\mathrm{Cd}$ affects animal and human health through the food chain by taking it up by plant roots (Ali et al., 2013). Plants do not require cadmium, but being poisonous to plants it can disrupt various physiological events (Kaya et al., 2019), such as restriction of respiration and photosynthesis (Song et al., 2019), disruption of the water relations (Belimov et al., 2015) and uptake of nutrient (Rasheed et al., 2018), and change in enzyme activity (Kaya et al., 2020). Besides, Cd toxicity can generate reactive oxygen species (ROS), causing oxidative stress by increasing lipid peroxidation and accumulating $\mathrm{H} 2 \mathrm{O} 2$ (Vasiljeva et al., 2018). The ROS molecules lead to oxidative damage of lipids, proteins, and nucleic acids resulting in cell death because of lipid peroxidation, membrane damage, and key enzymes' inhibition (Akram et al., 2018). Plants possess protective machinery to counteract the deleterious effects of Cd stress and minimize the accumulation of ROS (Chmielowska-Bak et al., 2018) by increasing the activities of key enzymatic antioxidants, such as peroxidase (POD), catalase (CAT), and superoxide dismutase (SOD) (Kaya et al., 2019).

Crops containing Cd play an important role in bringing this element into the human diet. Because more than $70 \%$ of $\mathrm{Cd}$ that enters the human body is transmitted through crops containing Cd (Rahimzadeh et al., 2017). Cd's natural concentration in plants is reported $0.05-2 \mathrm{mg} / \mathrm{kg}$ (Usman et al., 2019). There are two different ways to reduce the entry of $\mathrm{Cd}$ into the food chain. The first solution is to use refining methods to remove $\mathrm{Cd}$ from the soil. The second way to stabilize this soil element and reduce its attractiveness is through plants (Usman et al., 2019). Biological fertilizers use the second method to reduce this metal in plants and the human food chain (Wuana and Okieimen, 2011).

Arbuscular mycorrhizal fungi (AMF) can form intimate associations with the roots of about $85 \%$ of all terrestrial plants. They can significantly increase a plant's soil nutrients' uptake, especially phosphorus. Arbuscular mycorrhizal fungi are soil fungi, ubiquitous in all terrestrial ecosystems (Lou et al., 2014). They establish a symbiotic relationship with plant roots and, consequently, increase their host resistance to diverse biotic and/or abiotic stresses (Yao et al., 2014; Zou et al., 2014). Mechanisms used by AMF to reduce the stress of the heavy metal for plants include chelating and non-dynamics of heavy metals in foreign hyphae, improving mineral nutrition, especially phosphorus, altering root acidity, regulating gene expression in metal carriers, and affecting adsorption and absorption, etc. (Gupta et al., 2010; Luo et al., 2014). Numerous studies have also shown that living organisms, such as AMF, can alter the fragmentation (various forms and chemical forms) of heavy metals in the soil (Ruiz et al., 2011). Whitfield and Richards (2004) found that AMF increased the absorption of nutrients and improved the thyme plant's growth under heavy metal stress. Zhang et al. (2018) reported that AMF inoculation enhanced phosphorus absorption and plant growth and leaf CAT activity while decreasing heavy metal levels in the shoot of sunflower. Arbuscular mycorrhizal fungi mediate plant interaction by directly influencing plant biomass and/or indirectly influencing plant photosynthesis and macronutrient acquisition (Yang et al., 2016). The present experiment aimed to assess the effects of two AMF isolates on the morpho-physiological characteristics of thyme plants grown in contaminated soils with three different $\mathrm{Cd}$ concentrations. 


\section{Materials and Methods}

Plant materials and experimental design

To investigate the effect of different levels of AMF bio-fertilizers on morpho-physiological characteristics of thyme under $\mathrm{Cd}$ stress, a factorial experiment based on a completely randomized design in three replications including Cd at three levels: 0,75 , and $150 \mathrm{mg} / \mathrm{kg}$ soil and AMF in three levels without inoculation, inoculation with $F$. etunicatum and $F$. mosseae) was implemented in the greenhouse of Mohaghegh Ardabili University's, Ardabil City, Iran, in 2018.

The non-polluted soil sample with sandy loam texture was prepared from $0-30 \mathrm{~cm}$ depth of soil. After drying and passing through the $2 \mathrm{~mm}$ sieve, the samples were uniformly mixed and the physical, chemical, and biological characteristics were measured. Soil texture by hydrometer method (Gee and Bauder, 1986), organic matter content by dichromate wet-oxidation method (Ben-Dor and Banin, 1989), acidity by $\mathrm{pH}$ meter, electrical conductivity by EC meter, and calcium carbonate equivalent by Machado et al. (2014) method was measured and the results are presented in Table 1.

Cadmium at three levels of 0,75 , and $150 \mathrm{mg} / \mathrm{kg}$ soil was thoroughly mixed with each pot's soil by spraying cadmium chloride (CdCl2- Sigma-Aldrich). To achieve natural contamination, Cd-contaminated soils were exposed to wet and dry cycles for four months. Each seedling was inoculated with $10 \mathrm{ml}$ of a spore suspension of either F. etunicatum or F. mosseae (collected from Soil Biology Laboratory of Tabriz University, Iran), containing approximately 1000 spores, which was poured on the seedling roots. The control plants received $10 \mathrm{ml}$ of sterile water. Plants were uniformed in size, age and transplanted in $20 \times 35 \mathrm{~cm}$ plastic pots (one plant/pot) filled with $8 \mathrm{~kg}$ sandy-loam soil. Plants were watered as needed but were not fertilized, and each pot was placed in an individual saucer to allow reabsorption of irrigation water and avoid TM leaching. Plants were grown for three months in a greenhouse with 16 hours of daylight $\left(20-28^{\circ} \mathrm{C}\right)$. After the end of the threemonth planting period, the aerial and root sections were harvested separately in each pot. Samples of fresh roots were prepared to determine the percentage of root colonization. The dry weight of roots and aerial parts was measured at $72{ }^{\circ} \mathrm{C}$ for $72 \mathrm{~h}$ after washing and drying (Gerdeman and Nicolson, 1963).

Table 1. Some physical and chemical properties of soil

\begin{tabular}{|c|c|c|c|c|c|c|c|c|c|c|}
\hline $\begin{array}{c}\mathrm{EC} \\
(\mathrm{dS} / \mathrm{m})\end{array}$ & $\mathrm{pH}$ & $\begin{array}{c}\mathrm{CaCO}_{3} \\
(\%)\end{array}$ & $\begin{array}{c}\text { Organic } \\
\text { carbon } \\
(\%)\end{array}$ & $\begin{array}{c}\mathrm{N} \\
(\%)\end{array}$ & $\begin{array}{c}\mathrm{K} \\
(\%)\end{array}$ & $\begin{array}{c}\mathrm{P}(\%) \\
(\mathrm{ppm})\end{array}$ & Soil texture & $\begin{array}{c}\text { Clay } \\
(\%)\end{array}$ & $\begin{array}{c}\text { Silt } \\
(\%)\end{array}$ & $\begin{array}{c}\text { Sand } \\
(\%)\end{array}$ \\
\hline 4 & 7.3 & 19.1 & 0.514 & 0.12 & 0.05 & 3.8 & Sandy loam & 14 & 36 & 50 \\
\hline
\end{tabular}

\section{Measurement of traits}

The plant's morphological characteristics such as number of leaves, plant height, fresh and dry weight of stem and root organs were collected about two months after planting.

\section{Total soluble carbohydrate}

Samples of fresh leaves were weighed $(0.2 \mathrm{~g})$ and homogenized using $70 \%$ ethanol. Then they were filtered and pigments were removed by the use of benzene. An aliquot of $0.2 \mathrm{ml}$ of leaf extract was added to 1.0 $\mathrm{ml}$ of $0.2 \%$ anthrone to react in a water bath for $10 \mathrm{~min}$ at $100^{\circ} \mathrm{C}$. The test tube 3 was soon cooled in an ice bath and then the absorbance was recorded at $620 \mathrm{~nm}$, according to Yemm and Folkes (1953).

\section{Proline assay}

Proline was determined according to the method described by Bates et al. (1973). Approximately $0.5 \mathrm{~g}$ of fresh leaf material was homogenized in $10 \mathrm{ml}$ of $3 \%$ aqueous sulfosalicylic acid. Then, this aqueous solution was filtered through Whatman's paper No. 2. Finally, $2 \mathrm{ml}$ of filtrated solution was mixed with $2 \mathrm{ml}$ acidninhydrin and $2 \mathrm{ml}$ of glacial acetic acid in a test tube. The mixture was placed in a water bath for $1 \mathrm{~h}$ at 100 
${ }^{\circ} \mathrm{C}$. The reaction mixture was extracted with $4 \mathrm{ml}$ toluene, cooled to room temperature, and the absorbance was measured at $520 \mathrm{~nm}$ with a spectrometer.

\section{Antioxidant enzymes assay}

Samples were frozen in liquid nitrogen and stored at $-30{ }^{\circ} \mathrm{C}$. One g of frozen sample was homogenized in a mortar with $5 \mathrm{ml}$ of $50 \mathrm{mM}$ potassium phosphate buffer $(\mathrm{pH} 7.5)$ containing $1 \mathrm{mM}$ ethylenediaminetetraacetic acid (EDTA), $1 \mathrm{mM}$ dithiotreitol and $2 \%$ polyvinyl pyrrolidone (PVP). The homogenate was centrifuged at 15,000 $\mathrm{g}$ for $25 \mathrm{~min}$ and the supernatant was used for antioxidant enzyme assay (Aghighi Shahverdi et al., 2017).

\section{Catalase assay}

The CAT activity assay was performed using the Chance and Maehly (1995) method. Three ml reaction mixture containing $2.5 \mathrm{ml} 0.05 \mathrm{mM}$ sodium phosphate buffer $(\mathrm{pH}=7), 30 \mu \mathrm{g}$ protein solution was added to quettes. At the time of measurement, $30 \mu \mathrm{l} 30 \% \mathrm{H} 2 \mathrm{O} 2$ was added to the reaction mixture and the absorbance at $240 \mathrm{~nm}$, at $60 \mathrm{sec}$, and at $25^{\circ} \mathrm{C}$ was recorded spectrophotometrically. The control contained $2.5 \mathrm{ml}$ of sodium phosphate buffer and $30 \mu \mathrm{g}$ protein. Catalase activity was reported based on absorption alternations per $\mathrm{mg}$ protein per min.

\section{Peroxidase assay}

Peroxidase activity was assayed adopting the method of Polle et al. (1994) and Aghighi Shahverdi et al. (2018). According to this method, POD activity was determined at $436 \mathrm{~nm}$ by its ability to convert guaiacol to tetraguaiacol $\left(€=26.6 \mathrm{mM}^{-1} \mathrm{~cm}^{-1}\right)$. The reaction mixture contained $100 \mathrm{mM}$ potassium phosphate buffer $(\mathrm{pH}$ $=7.0), 20.1 \mathrm{mM}$ guaiacol, $10 \mathrm{mM} \mathrm{H} 2 \mathrm{O} 2$ and enzyme extract. The increase in absorbance was recorded by the addition of $\mathrm{H} 2 \mathrm{O} 2$ at $436 \mathrm{~nm}$ for $3 \mathrm{~min}$.

\section{Membrane stability index (MSI)}

Membrane stability index was estimated by taking leaf samples in $10 \mathrm{ml}$ of double-distilled water in two sets. One set was heated at $40^{\circ} \mathrm{C}$ for $30 \mathrm{~min}$ in a water bath and measured for electrical conductivity $(\mathrm{C} 1)$. The second set was boiled at $100^{\circ} \mathrm{C}$ for 10 min before having its conductivity (C2) measured. MSI was calculated according to the formula (1) as described by Sairam (1994):

$$
\mathrm{MSI}=(1-\mathrm{C} 1 / \mathrm{C} 2)
$$

\section{Root colonization}

To determine the percent of thyme root colonization by AFM treatment, Giovannetti and Mosse's modified method (1980) was used. The results showed that the root colonization average was above $40 \%$ in all treatments.

\section{Statistical analysis}

All data were analysed with Statistical Analysis System software (SAS Institute, Cary, NC, USA, Version 9.2), and the mean are significant differences were determined by LSD test at $\mathrm{p}<0.05 \%$. The Pearson correlation coefficient was used to measure relationships between morph-physiological trains by using SAS software vr.9.2. 


\section{Results}

\section{Plant height}

The effects of Cd, AFM, and Cd $\times$ AFM were significant ( $p=0.01)$ on plant height (Table 2). The highest plant height was achieved in the $F$. mosseae inoculation under no application $\mathrm{Cd}$ with an average of $49.4 \mathrm{~cm}$, which was a $44.3 \%$ increase compared to the control treatment. Non-inoculation under the high Cd stress level $(150 \mathrm{mg} / \mathrm{kg})$ showed the lowest means of this trait (Table 3$)$.

Table 2. Variance analysis (ANOVA) of the effect of AMF on the morpho-physiology characteristics of thyme (Thymus vulgaris $\mathrm{L}$.) under Cd stress conditions

\begin{tabular}{|c|c|c|c|c|c|c|c|c|c|c|c|c|}
\hline \multirow[b]{2}{*}{ S.O.V } & \multirow[b]{2}{*}{ df } & \multicolumn{11}{|c|}{ Mean square (MS) } \\
\hline & & $\begin{array}{l}\text { Plant } \\
\text { height }\end{array}$ & $\begin{array}{c}\text { Number of } \\
\text { leaves }\end{array}$ & $\begin{array}{c}\text { Stem fresh } \\
\text { weight }\end{array}$ & $\begin{array}{c}\text { Stem dry } \\
\text { weight }\end{array}$ & $\begin{array}{c}\text { Root fresh } \\
\text { weight }\end{array}$ & $\begin{array}{l}\text { Root dry } \\
\text { weight }\end{array}$ & MSI & $\begin{array}{l}\text { Proline } \\
\text { content }\end{array}$ & \begin{tabular}{|c|} 
Soluble \\
carbohydrate
\end{tabular} & $\begin{array}{l}\text { POD } \\
\text { activity }\end{array}$ & $\begin{array}{l}\text { CAT } \\
\text { activity }\end{array}$ \\
\hline $\begin{array}{l}\text { Cadmium } \\
(\mathrm{Cd})\end{array}$ & 2 & $417.6^{\star \star}$ & $4604.3^{\star *}$ & $2436.7^{\star *}$ & $353.59^{\star *}$ & $2436.7^{\star \star}$ & $417.7^{* *}$ & $6.8^{* *}$ & $0.1^{\star \star}$ & $0.014^{\star \star}$ & $19.37^{\star *}$ & $6.87^{* *}$ \\
\hline AFM & 2 & $124.6^{* *}$ & $1285.3^{\star \star}$ & $360.1^{\star \star}$ & $98.54^{*}$ & $360.11^{\star \star}$ & $124.7^{\star \star}$ & $12.9^{* \star}$ & $0.021^{\star *}$ & $0.017^{\star \star}$ & $27.49^{\star *}$ & $12.97^{\star *}$ \\
\hline $\mathrm{Cd} \times \mathrm{AFM}$ & 4 & $8.61^{* *}$ & $49.1^{* *}$ & $7.8^{\star \star}$ & $13.77^{* *}$ & $7.77^{\star \star}$ & $8.60^{* *}$ & $0.14 \mathrm{~ns}$ & $0.0008 \mathrm{~ns}$ & $0.00016 \mathrm{~ns}$ & $27.42^{\star \star}$ & $0.14 \mathrm{~ns}$ \\
\hline Erorr & 54 & 0.34 & 4.00 & 1.00 & 0.33 & 1.00 & 0.34 & 0.39 & 0.003 & 0.0012 & 3.25 & 0.203 \\
\hline CV $(\%)$ & - & 5.67 & 4.38 & 11.54 & 6.52 & 8.33 & 5.00 & 13.6 & 11.19 & 20.4 & 4.14 & 11.2 \\
\hline
\end{tabular}

AMF: Arbuscular mycorrhizal fungi; MSI: Membrane stability index; POD: Peroxidase; CAT: Catalase

Table 3. Interaction AMF $\times \mathrm{Cd}$ on morphological traits and POD activity of thyme (Thymus vulgaris L.)

\begin{tabular}{|c|c|c|c|c|c|c|c|c|}
\hline $\begin{array}{c}\mathrm{Cd} \\
\text { concentration } \\
\text { (mg/kg of soil) }\end{array}$ & AMF treatment & $\begin{array}{l}\text { Plant } \\
\text { height } \\
(\mathrm{cm})\end{array}$ & $\begin{array}{c}\text { Number of } \\
\text { leaves per } \\
\text { plant }\end{array}$ & $\begin{array}{l}\text { Stem fresh } \\
\text { weight } \\
\text { (g/plant) }\end{array}$ & $\begin{array}{c}\text { Stem dry } \\
\text { weight } \\
\text { (g/plant) }\end{array}$ & $\begin{array}{l}\text { Root fresh } \\
\text { weight } \\
\text { (g/plant) }\end{array}$ & $\begin{array}{c}\text { Root dry } \\
\text { weight } \\
\text { (g/plant) }\end{array}$ & $\begin{array}{l}\text { POD activity } \\
\text { (U/mg } \\
\text { protein.min) }\end{array}$ \\
\hline \multirow{3}{*}{ Control } & non-inoculated & $27.49 \mathrm{~d}$ & $163.1 \mathrm{e}$ & $87.3 \mathrm{~d}$ & $14.16 \mathrm{~d}$ & $95 \mathrm{~d}$ & $17.29 \mathrm{~d}$ & $43.6 \mathrm{i}$ \\
\hline & $\begin{array}{l}\text { Funneliformis } \\
\text { etunicatum }\end{array}$ & $36.16 \mathrm{~b}$ & $185.4 \mathrm{~b}$ & $93.2 \mathrm{~b}$ & $22.86 \mathrm{~b}$ & $102 \mathrm{~b}$ & $25.96 \mathrm{~b}$ & $55.0 \mathrm{f}$ \\
\hline & $\begin{array}{c}\text { Funneliformis } \\
\text { mosseae }\end{array}$ & $49.40 \mathrm{a}$ & $196.2 \mathrm{a}$ & $101.0 \mathrm{a}$ & $27.19 a$ & $110 \mathrm{a}$ & $30.29 a$ & $60.3 c$ \\
\hline \multirow{3}{*}{75} & non-inoculated & $24.84 \mathrm{e}$ & $158.3 \mathrm{f}$ & $81.7 \mathrm{f}$ & $11.56 \mathrm{e}$ & $90 \mathrm{f}$ & $15.26 \mathrm{e}$ & $47.6 \mathrm{~h}$ \\
\hline & $\begin{array}{l}\text { Funneliformis } \\
\text { etunicatum }\end{array}$ & $26.66 \mathrm{~d}$ & $173.1 \mathrm{~d}$ & $86.6 \mathrm{~d}$ & $13.36 \mathrm{~d}$ & $96 \mathrm{~d}$ & $16.46 \mathrm{~d}$ & $56.3 \mathrm{e}$ \\
\hline & $\begin{array}{c}\text { Funneliformis } \\
\text { mosseae }\end{array}$ & $28.76 \mathrm{c}$ & $180.7 \mathrm{c}$ & $89.4 \mathrm{c}$ & $15.46 \mathrm{c}$ & $98 \mathrm{c}$ & $18.56 \mathrm{c}$ & $64.4 \mathrm{~b}$ \\
\hline \multirow{3}{*}{150} & non-inoculated & $20.66 \mathrm{~h}$ & $146.8 \mathrm{~h}$ & $71.4 \mathrm{j}$ & $7.36 \mathrm{~h}$ & $80 \mathrm{k}$ & $10.46 \mathrm{hi}$ & $53.6 \mathrm{~g}$ \\
\hline & $\begin{array}{c}\text { Funneliformis } \\
\text { etunicatum }\end{array}$ & $22.26 \mathrm{~g}$ & $153.6 \mathrm{~g}$ & $76.7 \mathrm{~h}$ & $8.96 \mathrm{~g}$ & $85 \mathrm{~h}$ & $12.06 \mathrm{~g}$ & $59.3 \mathrm{~d}$ \\
\hline & $\begin{array}{c}\text { Funneliformis } \\
\text { mosseae }\end{array}$ & $23.86 \mathrm{f}$ & $160.3 \mathrm{ef}$ & $74.3 \mathrm{ij}$ & $10.56 \mathrm{f}$ & 83 ij & $13.46 \mathrm{f}$ & $72.5 \mathrm{a}$ \\
\hline
\end{tabular}

Means in each column followed by a similar letter (s), are not significantly different at $5 \%$ probability level, using LSD Test

\section{Number of leaves}

Cadmium stress, AMF, and interaction Cd $\times$ AMF treatments, as shown in Table 2 affected the leaves' number of thyme plants ( $p=0.01$ ). The inoculation by $F$. mosseae under free $\mathrm{Cd}$ conditions showed the highest number of leaves (196.2 per plant). Non-inoculated treatment under $150 \mathrm{mg} / \mathrm{kg}$ Cd stress decreased number of leaves $(9.99 \%)$ compared to the control treatment (Table 3).

\section{Stem fresh and dry weight}

Stem fresh and dry weight significantly affected by Cd, AFM, and Cd $\times$ AMF (Table 2). As shown in Table 3, a drastic decline in stem fresh and dry weight was observed due to $\mathrm{Cd}$ stress. On the other hand, the inoculation of AMF enhanced these parameters and ameliorated Cd stressinduced decline. Due to the inoculation of AMF (F. mosseae) under $150 \mathrm{mg} / \mathrm{kg} \mathrm{Cd}$, stem fresh and dry weight 
were enhanced by 3.9 and $30.3 \%$, respectively, compared to non-inoculated and $150 \mathrm{mg} / \mathrm{kg} \mathrm{Cd}$. The lowest of these traits related to the non-inoculated AMF under the high level of Cd stress (Table 3).

\section{Root fresh and dry weight}

Root fresh and dry weight was significantly affected by Cd, AMF, and Cd $\times$ AMF treatments (Table 2). Root fresh and dry weight decreased drastically due to $\mathrm{Cd}$ stress and however, AMF inoculation increased their traits and ameliorated the Cd-induced reduction. Cadmium stress $(150 \mathrm{mg} / \mathrm{kg}+$ non-inoculated $)$ reduced root fresh and dry weight by 15.7 and 39.5\%, while in AMF (F. mosseae) inoculated Cd stressed $(150 \mathrm{mg} / \mathrm{kg}+$ AMF) plants reduction was only 12.6 and $22.1 \%$ (Table 3 ).

\section{Membrane stability index}

As shown in Table 2, the effects of Cd and AMF were significant on MSI $(p=0.01)$. Membrane stability index decreased in Cd stressed $(150 \mathrm{mg} / \mathrm{kg})$ plants. This reduction was $19.8 \%$ compared to the control treatment. Inoculated plants with AFM showed enhanced MSI compared to the non-inoculated treatment, this increase was $25.1 \%$ under F. mosseae application (Table 4 ).

Table 4. The effects of Cd and AMF treatments on some physiological traits of thyme (Thymus vulgaris L.)

\begin{tabular}{|l|c|c|c|c|}
\hline $\begin{array}{c}\text { Cd concentrations } \\
(\mathrm{mg} / \mathrm{kg} \text { of soil })\end{array}$ & $\begin{array}{c}\text { MSI } \\
(\%)\end{array}$ & $\begin{array}{c}\text { Proline content } \\
(\mu \mathrm{mol} / \mathrm{g} \mathrm{FW})\end{array}$ & $\begin{array}{c}\text { Soluble carbohydrate } \\
\text { content }(\mu \mathrm{g} / \mathrm{g} \mathrm{FW})\end{array}$ & $\begin{array}{c}\text { CAT activity }(\mathrm{U} / \mathrm{mg} \\
\text { protein.min })\end{array}$ \\
\hline Control & $5.03 \mathrm{a}$ & $0.47 \mathrm{c}$ & $0.147 \mathrm{~b}$ & $3.50 \mathrm{c}$ \\
\hline 75 & $4.65 \mathrm{~b}$ & $0.51 \mathrm{~b}$ & $0.177 \mathrm{a}$ & $4.12 \mathrm{~b}$ \\
\hline 150 & $4.03 \mathrm{c}$ & $0.59 \mathrm{a}$ & $0.192 \mathrm{a}$ & \\
\hline & & & & $3.50 \mathrm{a}$ \\
\hline AMF treatments & & & $0.145 \mathrm{~b}$ & $3.24 \mathrm{c}$ \\
\hline Non-inoculated & $3.77 \mathrm{c}$ & $0.49 \mathrm{c}$ & $0.177 \mathrm{a}$ & $4.36 \mathrm{~b}$ \\
\hline $\begin{array}{l}\text { Funneliformis } \\
\text { etunicatum }\end{array}$ & $4.89 \mathrm{~b}$ & $0.52 \mathrm{~b}$ & $0.194 \mathrm{a}$ & $4.51 \mathrm{a}$ \\
\hline Funneliformis mosseae & $5.04 \mathrm{a}$ & $0.53 \mathrm{a}$ & $\mathrm{u}$ & \\
\hline
\end{tabular}

Means in each column followed by a similar letter (s), are not significantly different at $5 \%$ probability level, using LSD Test

\section{Free proline content}

Leaves free proline content affected by Cd stress and AFM inoculation (Table 2). Cadmium stress and AMF application increased proline content. In comparison to control, we achieved 20.3 and $7.54 \%$ increases in $150 \mathrm{mg} / \mathrm{kg} \mathrm{Cd}$ stress and F. mosseae inoculated treatments (Table 4).

\section{Soluble carbohydrate content}

As shown in Table 2, the effects of Cd stress and AMF inoculated treatments were significant on the soluble carbohydrate content. The highest soluble carbohydrate content was related to the 75 and $150 \mathrm{mg} / \mathrm{kg}$ Cd levels ( 0.177 and $0.192 \mu \mathrm{g} / \mathrm{g} \mathrm{FW})$ and inoculated with F. etunicatum and F. mosseae $(0.177$ and $0.194 \mu \mathrm{g} / \mathrm{g}$ FW). Control treatment (free $\mathrm{Cd}$ stress and non-inoculated treatments) showed the lowest means of the trait (Table 4).

\section{Peroxidase activity}

As shown in Table 2, POD activity is affected by Cd, AMF, and Cd $\times$ AMF treatments $(p=0.01)$. Results indicated that the Cd stress and AFM inoculation treatments increased POD activity. According to the interaction effect of $\mathrm{Cd} \times \mathrm{AMF}$, the highest and lowest POD activity (72.5 and $43.6 \mathrm{U} / \mathrm{mg}$ protein.min) was related to the inoculation of $F$. mosseae under $150 \mathrm{mg} / \mathrm{kg}$ Cd levels and non-inoculated under free Cd stress conditions, respectively (Table 3 ). 


\section{Catalase activity}

The effects of Cd stress and AFM treatments were significant on CAT activity (Table 2). As shown in Table 4, Cd stress and AFM inoculated enhanced CAT activity. This enzyme's highest activity was observed in $150 \mathrm{mg} / \mathrm{kg}$ Cd levels and inoculation with $F$. mosseae which, compared to the control treatment, showed 22.2 and $28.1 \%$ increases, respectively. Control treatments had the lowest activity (Table 4).

\section{Correlation analysis}

The results of the simple correlation (Pearson) presented in Table 5. Based on this table's results, morphological traits such as plant height, number of leaves, stem fresh and dry weight, and root fresh and dry weight were positively and significantly correlated. Among the physiological parameters, soluble carbohydrates had a positive and significant correlation with stem fresh and dry weight, root fresh weight, MSI, proline content, and activity of CAT and POD enzymes.

Table 5. Correlation coefficients among morph-physiological traits of thyme (Thymus vulgaris L.) under AMF and Cd treatments

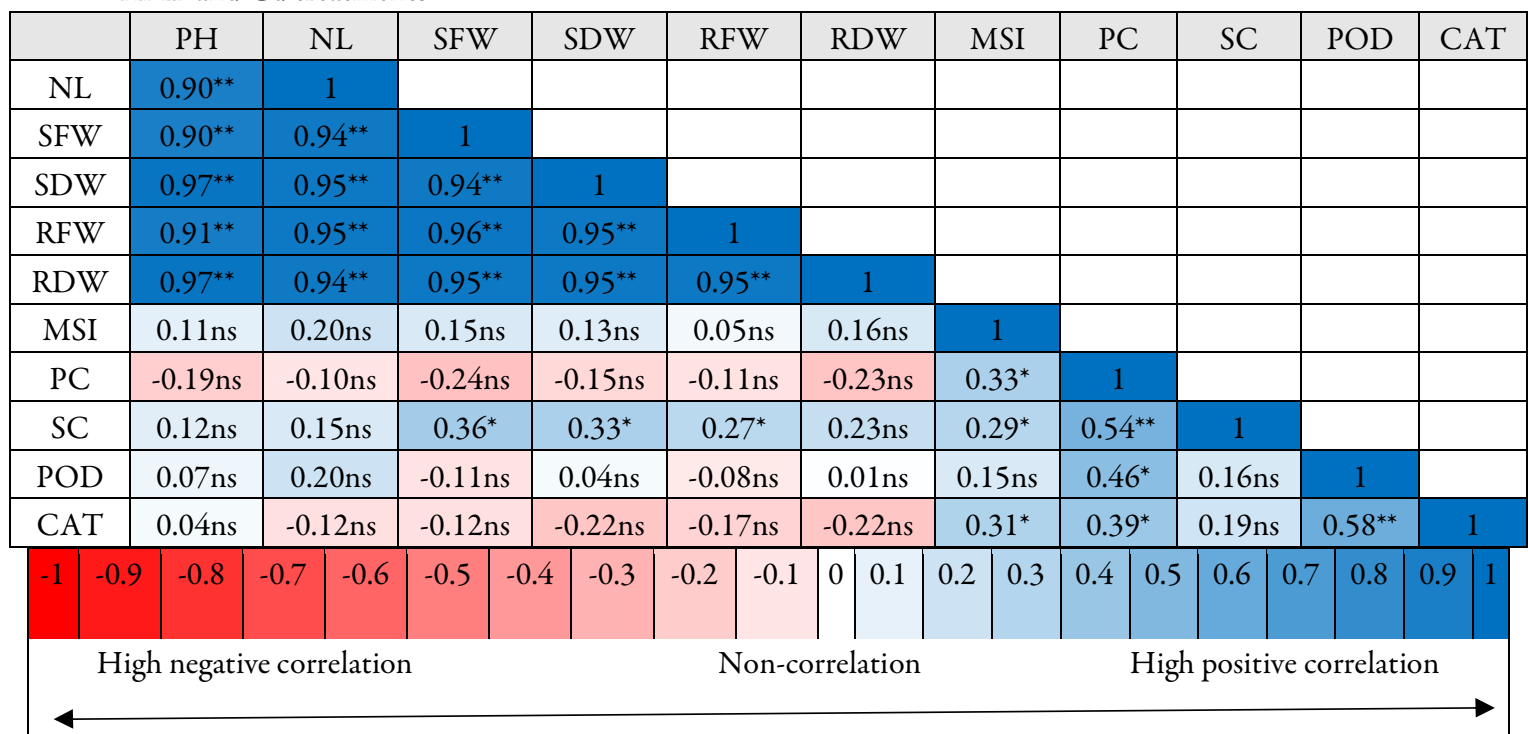

ns: non-significant; ${ }^{*}$ and ${ }^{* *}$ significant at 5 and $1 \%$ probably levels, respectively

AMF: arbuscular mycorrhizal fungi; Cd: cadmium; PH: plant height; NL: number of leaves; SFW: stem fresh weight; SDW: stem dry weight; RFW: root fresh weight; RDW: root dry weight; MSI: membrane stability index; PC: proline content; SC: soluble carbohydrate; POD: peroxidase activity; CAT: catalase activity

\section{Discussion}

Cadmium stress has been shown to induce many morpho-physiological modifications in plants, which is dependent upon plant species, organ/tissue, the concentration of metal, and exposure period (Abdelhameed and Metwally, 2019). Cd stress drastically reduced growth parameters such as plant height, number of leaves, stem fresh and dry weight, and root fresh and dry weight in the current study. Heavy metals such as Cd appear to inhibit plant growth in a variety of ways. On the one hand, heavy metals, by reducing cell turgor, reduce cell division and inhibit cell growth, and on the other hand, by accumulating in the cell wall and entering the cytoplasm and disrupting the cell's natural metabolism, they lead to reduced growth (Abdelhameed and Metwally, 2019). An examination of the cabbage plant showed that by increasing Cd's concentration in the plant environment, the weight of the plant was reduced (Ali et al., 2015). 
In the current study, Cd stress decreased MSI. The first sign of Cd oxidative stress is the proliferation of lipid cell membranes, which is followed by an increase in lipid peroxidation, destroyed cell membranes, and ion leakage, and then a decrease in MSI and an increase MDA, which are two indicators for measuring damage to biological membranes (Siddhu and Ali, 2012).

In our results, as $\mathrm{Cd}$ concentrations in the soil increased, leaf proline levels increased significantly, corresponding to the results of Dinakar et al. (2008) in peanuts, Zhao (2011) in wheat and corn. Plants exposed to adverse environmental conditions show enhanced synthesis and accumulation of osmolytes which have an important role in maintaining growth under stressed conditions (Alqarawi et al., 2014). Proline is among the important osmolytes involved in the maintenance of tissue water content. In the current study, an increase in proline accumulation due to $\mathrm{Cd}$ stress was obvious and a further increase caused by AMF inoculation confirms the role of AMF in strengthening the stress tolerance mechanisms in plants. Under stress conditions, proline synthesizing enzymes' activity is upregulated while its catabolism is lowered (Hashem et al., 2014). Proline and other osmolyte accumulation such as soluble carbohydrate help plants to maintain cellular water potential well below that of the soil solution. Our results of proline accumulation due to $\mathrm{Cd}$ stress are in agreement with the results of Irfan et al. (2014), Abd_Allah et al. (2015), and Hashem et al. (2016) in Brassica juncea, Helianthus annus L. and Cassia italica Mill, respectively. Enhancement in proline in our study supports the role of proline in maintaining growth under stress conditions. An increase in proline due to AMF inoculation is in corroboration with the results of Shekoofeh et al. (2012) and Hashem et al. (2016). Proline has a protective role for protecting membranes and other cellular molecules like enzymes and neutralizes toxic ROS, therefore contributing to better growth under stress conditions (Irfan et al., 2014). By reducing water transfer to the leaves and slowing down the transpiration rate, Cd changes key enzymes' behaviour in the metabolism of sugars and increases the amount of soluble carbohydrates in the cell.

The coexistence of AMF with roots by absorbing water and nutrients increases photosynthesis, leading to more crop production and improved growth (Begum et al., 2019). On the other hand, AMF by increases soil health parameters (soil moisture, fertility levels, and soil quality), nutrients uptake and regulation of Aquaporin gene (AQP), ABA-responsive gene, phytohormone biosynthesis pathways, and Transcription factors were improved stress tolerance (Begum et al., 2019). These results are consistent with other researchers' findings on the positive effect of AMF in increasing plant dry matter (Wu and Xia, 2006). In another report, inoculation of plant roots of dill and cumin with two types of AMF significantly increased their aerial parts' dry weight compared to non-mycorrhizal plants (Kapoor et al., 2004).

In general, AMF prevents carbohydrate intake by increasing the soluble sugars, and by maintaining the osmotic pressure and water content of the leaves, they lead to cell growth and increase plant growth (Yooyongwech et al., 2013). Improved plant growth and production in AMF-associated plants under stress have been linked to the optimization of biochemical changes (Miransari, 2010). Yooyongwech et al. (2013) stated the AMF regulates growth under stress conditions by modifying proline and sugar contents. Cordero et al. (2004) showed that the levels of fructose, $\alpha$-glucose, $\beta$-glucose, sucrose, as well as the total sugar content in peppers coexisting with AFM, were significantly higher than control plants (non-AFM). Another reason for these fungi' effect on increasing soluble carbohydrate content is to increase the levels of plant hormones such as cytokinin and gibberellin in inoculated plants. Increased levels of these hormones, especially cytokinin, can increase photosynthesis rate and ultimately increase the carbohydrate content of plants by transferring ions that are effective in opening the pores and regulating chlorophyll levels (Chanclud and Moral, 2016).

In the current study, the colonization of AFM to thyme plant in the Cd stress conditions was significantly higher than that in the free $\mathrm{Cd}$ stress conditions. Zhang et al. (2018) reported that the root with AMF inoculation often enhances phosphorous absorption and plant growth by tapping a larger soil volume than that without inoculation for the relatively immobile phosphorous solubilizing normally insoluble phosphorous sources through the excretion of various organic acids. Meanwhile, the higher phosphorous absorption by plants upon AMF inoculations also seemed to be due to the elevation of soil phosphatase activity, which may involve AMF directly and indirectly: AMF propagules can synthesize such enzymes, and 
mycorrhizal roots may release more root exudates containing enzymes due to the improved nutrition and/or larger root system (Hu et al., 2014). As a result, the observed large increases in the phosphorous acquisition and thus plant biomass of sunflower following both inoculation treatments were mostly due to the enhanced root mycorrhizal colonization rate and soil phosphatase activity (Zhang et al., 2018).

Abdelhameed and Metwally (2019) reported plants had developed a series of mechanisms to cope with Cd pollution, among which AMF is considered an effective strategy to alleviate Cd phytotoxicity. Cadmium can be immobilized in the fungal hyphae of internal and external origin that can fix $\mathrm{Cd}$ in the cell wall and store them in the vacuole or may chelate with some other substances in the cytoplasm and hence reduce Cd toxicity in the plants (Punamiya et al., 2010; Begum et al., 2019). Li et al. (2016) indicated that AMF was very effective in lowering $\mathrm{Cd}$ levels, which brought about $\mathrm{Cd}$ detoxification in rice plants.

The strong effects of AMF on plant development and growth under heavy metals stressful conditions are most often due to the ability of these fungi in increasing morphological and physiological processes that increase plant biomass and consequently uptake of important immovable nutrients (notably $\mathrm{P}$ ) and thus reduced metal toxicity in the host plants (Kanwal et al., 2015; Miransari, 2017). On the one hand, AM fungi can make a considerable contribution to nutrient (notably phosphorus) uptake to promote plant growth. Besides, AMF can alleviate heavy metals toxicity on plants in polluted soil by the reduction of heavy metal acquisitions, the biological dilution of heavy metals, and the decrease of oxidative stress (Neagoe et al., 2014; Zhang et al., 2018).

Antioxidant enzymes play an important role in scavenging ROS and averting the oxidative stress that prompted numerous sensitive molecules' damaging effects. In the present study, results showed an increase in CAT and POD activities of thyme with Cd application. These results are in good agreement with those of Chaturvedi et al. (2018) and Abdelhameed and Metwally (2019) that can be attributed to ROS's overproduction overexpression of genes coding for antioxidant enzymes. This result, which increases with increasing stress on the activity of antioxidant enzymes, indicates the effectiveness of the antioxidant system in plant protection and is compatible with the results obtained by Nas and Ali (2018) as a study the of effects of lead and $\mathrm{Cd}$ the growth and activity of some spinach enzymes. The highest activity of CAT enzyme was obtained in soil inoculation with $F$. mosseae mycorrhizal fungus, which was significantly higher than other treatments, and the lowest activity was observed in the soilless treatment of fungi (control) which is consistent with the results of Tan et al. (2015) on two species of Solanum hoteinocarpum.

Our result indicated that the application of AFM enhanced CAT and POD activities. In this regard, in a study conducted by Dehghani et al. (2017), AFM-corn had significantly higher CAT activity than non-AFM. The present study results are consistent with the results of Nareshkomar et al. (2015) on peanut plants.

The results indicate that these AMF strains mediate different tolerance strategies to alleviate $\mathrm{Cd}$ toxicity in their host plants and that inoculation with both AMFs can be used for Cd phytoextraction. In contrast, this F. mosseae strain can be useful for $\mathrm{Cd}$ of contaminated soil. The present study results showed that in the comparison between the two fungi, F. mosseae had a higher efficiency in increasing morphological traits and improving physiological traits compared to F. etunicatum.

\section{Conclusions}

In conclusion, $\mathrm{Cd}$ stress affected growth and morpho-physiological characteristics in the thyme plant. This study's overall results showed that the presence of $\mathrm{Cd}$ in the culture medium affected the growth and morphological characteristics of thyme and reduced growth and disruption of various physiological processes in plant structure. The increased activity of antioxidant enzymes in this study could reduce the production of reactive oxygen species (ROS) that can inhibit growth by creating oxidative stress. In fact, by increasing the CAT and POD enzyme effect, especially at a concentration of $150 \mathrm{mg} / \mathrm{kg} \mathrm{Cd}$ and the loss of $\mathrm{H} 2 \mathrm{O} 2$ in the plant, the lipid peroxidation index decreases. Also, thyme inoculation with AMF in terms of vegetative and 
morphological traits such as plant height, number of leaves, stem fresh and dry weight, and root fresh and dry weight has reduced $\mathrm{Cd}$ stress. AMF inoculation (especially $F$. mosseae) mitigated $\mathrm{Cd}$ stress's damaging impact by reducing the enhancing the antioxidant activity, proline, and soluble carbohydrate contents and lipid peroxidation. The present study strongly supports employing AMF (especially $F$. mosseae) as the biological fertilizer for enhancing the $\mathrm{Cd}$ stress tolerance of thyme plants.

\section{Authors' Contributions}

RR collected and analyzed the data used in manuscript, and drafted the manuscript. SAH and BE supervised the project. AE and GS Edited final approval of the version to be submitted. All authors read and approved the final manuscript.

\section{Acknowledgements}

This research received no specific grant from any funding agency in the public, commercial, or not-forprofit sectors.

\section{Conflict of Interests}

The authors declare that there are no conflicts of interest related to this article.

\section{References}

Abd_Allah EF, Hashem A, Alqarawi AA, Alwathnani HA (2015). Alleviation of adverse impact of cadmium stress in sunflower (Helianthus annuus L.) by arbuscular mycorrhizal fungi. Pakistan Journal of Botany 47(2):785-795.

Abdelhameed RE, Metwally RA (2019). Alleviation of cadmium stress by arbuscular mycorrhizal symbiosis. International Journal of Phytoremediation 21:663-671. https://doi.org/10.1080/15226514.2018.1556584

Aghighi Shahverdi M, Omidi H, Tabatabaei SJ (2017). Effect of nutri-priming on germination indices and physiological characteristics of stevia seedling under salinity stress. Journal of Seed Science 39(4):353-362. https://doi.org/10.1590/2317-1545v39n4172539

Aghighi Shahverdi M, Omidi H, Tabatabaei SJ (2018). Morpho-physiological response of stevia (Stevia rebaudiana Bertoni) to salinity under hydroponic culture condition (a case study in Iran). Applied Ecology and Environmental Research 16(1):17-28. https://doi.org/10.15666/aeer/1601_017028

Akram NA, Iqbal M, Muhammad A, Ashraf M, Al-Qurainy F, Shafiq S (2018). Aminolevulinic acid and nitric oxide regulate oxidative defense and secondary metabolisms in canola (Brassica napus L.) under drought stress. Protoplasma 255:163-174. https://doi.org/10.1007/s00709-017-1140-X

Ali A, Deng X, Hu X, Gill RA, Ali S, Wang S, Zhou W (2015). Deteriorative effects of cadmium stress on antioxidant system and cellular structure in germinating seeds of Brassica napus L. Journal of Agricultural Science and Technology 17:63-74.

Ali S, Farooq MA, Hussain S, Yasmeen T, Abbasi GH, Zhang G (2013). Alleviation of chromium toxicity by hydrogen sulfide in barley. Environmental Toxicology Chemistry 10:2234-2239. https://doi.org/10.1002/etc.2309

Alqarawi AA, Abd-Allah EF, Abeer H (2014). Alleviation of salt-induced adverse impact via mycorrhizal fungi in Ephedra aphylla Forssk. Journal of Plant Interactions 9(1):802-810. https://doi.org/10.1080/17429145.2014.949886

Bates LS, Waldern RP, Teave ID (1973). Rapid determination of free proline for water stress studies. Plant and Soil 39:205-107. https://doi.org/10.1007/BF00018060 
Begum N, Qin C, Ahanger MA, Raza S, Khan MI, Ashraf M, ... Zhang L (2019). Role of arbuscular mycorrhizal fungi in plant growth regulation: implications in abiotic stress tolerance. Frontiers in Plant Science 10:1068. https://doi.org/10.3389/fpls.2019.01068

Belimov AA, Dodd IC, Safronova VI, Malkov NV, Davies WJ, Tikhonovich IA (2015). The cadmium-tolerant pea (Pisum sativum L.) mutant SGECdt is more sensitive to mercury: assessing plant water relations. Journal of Experimental Botany 66(8):2359-2369. https://doi.org/10.1093/jxb/eru536

Ben-Dor E, Banin A (1989). Determination of organic matter content in arid-zone soils using a simple "loss-on-ignition" method. Communications in Soil Science and Plant Analysis 20(16):1675-1695. https://doi.org/10.1080/00103628909368175

Chance B, Maehly AC (1995). Assay of catalase and peroxidase. New York, NY: Academic Press, pp 764-775. https://doi.org/10.1016/S0076-6879(55)02300-8

Chanclud E, Moral JB (2016). Plant hormones: A fungal point of view. Molecular Plant Pathology 17(8):1289-1297. https://doi.org/10.1111/mpp.12393

Chaturvedi R, Favas PJC, Pratas J, Varun M, Paul MS (2018). Effect of Glomus mossae on accumulation efficiency, hazard index and antioxidant defense mechanisms in tomato under metal (loid) stress. International Journal of Phytoremediation 20(9):885-894. https://doi.org/10.1080/15226514.2018.1438360

Chmielowska-Bak J, Izbianska K, Ekner-Grzyb A, Bayar M, Deckert J (2018). Cadmium stress leads to rapid increase in RNA oxidative modifications in soybean seedlings. Front. Plant Science 8:2219. https://doi.org/10.3389/fpls.2017.02219

Cordero B, Lodeiro P, Herrero R, Esteban Sastre de Vicente M (2004). Biosorption of cadmium by Fucus spiralis. Environmental Chemistry 1:180-187. https://doi.org/10.1071/EN04039

Dehghani AS, Kazemeini A, Zarei M, Alinia M (2017). Effects of salt stress and mycorrhiza fungi on morpho-physiological characteristics of sweet corn (Zea mays var. saccharata). Journal of Crop Production and Processing 7(1):101112. https://doi.org/10.18869/acadpub.jcpp.7.1.101

Dinakar N, Nagajyothi PC, Suresh S, Udaykiran Y, Damodharam T (2008). Phytotoxicity of cadmium on protein, proline and antioxidant enzyme activities in growing Arachis hypogaea L. seedlings. Environmental Science 20:199-206. https://doi.org/10.1016/S1001-0742(08)60032-7

Gee GW, Bauder JW (1986). Particle-size analysis. In: Page AL (Ed). Methods of Soil Analysis. Part 1. Physical and Mineralogical Methods. Second Edition, Agronomy Monograph 9, American Society of Agronomy, Madison, WI, pp 383-411.

Gerdeman JW, Nicolson TH (1963). Spores of mycorrhizal endogone species extracted from soil by wet sieving and decanting. Transactions of the British Mycological Society 46:235-244. https://doi.org/10.1016/S00071536(63)80079-0

Giovannetti M, Mosse B (1980). An evaluation of techniques for measuring vesicular-arbuscular mycorrhizal infection in roots. New Phytologist 84:489-500.

Gupta AP, Dhar JK, Sharma G, Ram G, Bedi YS (2010). Volatile (As and Hg) and non-volatile (Pb and Cd) toxic heavy metals analysis in rhizome of Zingiber officinale collected from different locations of North Western Himalayas by atomic absorption spectroscopy. Food Chemical Toxicology Journal 8(10):2966-2971. https://doi.org/10.1016/j.fct.2010.07.034

Hashem A, Abd-Allah EF, Alqarawi AA, Egamberdieva D (2016). Bioremediation of adverse impact of cadmium toxicity on Cassia italica Mill by arbuscular mycorrhizal fungi. Saudi Journal of Biological Sciences 23:39-47. http://dx.doi.org/10.1016/j.sjbs.2015.11.007

Hashem A, Abd_Allah EF, Alqarawi AA, El-Didamony G, Alwhibi Mona S, Egamberdieva D, Ahmad P (2014). Alleviation of adverse impact of salinity on faba bean (Vicia faba L.) by arbuscular mycorrhizal fungi. Pakistan Journal Botany 46(6):2003-2013.

Hu J, Wang H, Wu F, Wu S, Cao Z, Lin X, Wong MH (2014). Arbuscular mycorrhizal fungi influence the accumulation and partitioning of $\mathrm{Cd}$ and $\mathrm{P}$ in bashful grass (Mimosa pudica L.) grown on a moderately Cd-contaminated soil. Applied Soil Ecology 73:51-57. https://doi.org/10.1016/j.apsoil.2013.08.010

Irfan M, Ahmad A, Hayat S (2014). Effect of cadmium on the growth and antioxidant enzymes in two varieties of Brassica juncea L. Saudi Journal of Biological Sciences 21:125-131. https://doi.org/10.1016/j.sjbs.2013.08.001

Kabir M, Iqbal MZ, Shafiq M, Farroqi ZR (2018). The effects of lead and cadmium individually and in combinations on germination and seedling growth of Leucaena leucocephala (Lam). American Scientific Research Journal for Engineering, Technology, and Sciences 43:33-43. 
Kalvandi R, Mirza M, Atri M, Hesamzadeh Hejazi M, Jamzad Z, Safikhan K (2014). Introduction of seven new chemotypes of Thymus eriocalyx (Ronniger) Jalas in Iran based upon the variation of essential oil composition in different populations. Iranian Journal Medicinal and Aromatic Plants 30:101-22.

Kanwal S, Bano A, Malik RN (2015). Effects of arbuscular mycorrhizal fungi on metals uptake, physiological and biochemical response of Medicago sativa L. with increasing $\mathrm{Zn}$ and $\mathrm{Cd}$ concentrations in soil. American Journal of Plant Sciences 6:2906-2923. https://doi.org/10.4236/ajps.2015.618287

Kapoor R, Giri B, Mukerji KG (2004). Improved growth and essential oil yield and quality in Foeniculum vulgare on mycorrhizal inoculation supplemented with P-fertilizer. Journal of Biological Resource Technology 93:307-311. https://doi.org/10.1016/j.biortech.2003.10.028

Kaya C, Akram NA, Surucu A, Ashraf M (2019). Alleviating effect of nitric oxide on oxidative stress and antioxidant defence system in pepper (Capsicum annuum L.) plants exposed to cadmium and lead toxicity applied separately or in combination. Scientia Horticulturae 255:52-60. https://doi.org/10.1016/j.scienta.2019.05.029

Kaya C, Ashraf M, Alymeni MN, Ahmad P (2020). The role of nitrate reductase in brassinosteroid-induced endogenous nitric oxide generation to improve cadmium stress tolerance of pepper plants by upregulating the ascorbateglutathione cycle. Ecotoxicology and Environmental Safety 196:110483. https://doi.org/10.1016/j.ecoenv.2020.110483

Kucukaydin S, Tel-Cayan G, Duru ME, Kesdek M, Ozturk M (2020). Chemical composition and insecticidal activities of the essential oils and various extracts of two Thymus species: Thymus cariensis and Thymus cilicicus. Toxin Reviews. https://doi.org/10.1080/15569543.2020.1731552

Li H, Luo N, Zhang LJ, Zhao HM, Li YW, Cai QY (2016). Do arbuscular mycorrhizal fungi affect cadmium uptake kinetics, subcellular distribution and chemical forms in rice? Science of the Total Environment 571:1183-1190. https;//doi.org/10.1016/j.scitotenv.2016.07.124

Luo Z, Wu C, Zhang C, Li H, Lipka U, Polle A (2014). The role of ectomycorrhizas in heavy metal stress tolerance of host plants. Environmental and Experimental Botany 108:47-62. https://doi.org/10.1016/j.envexpbot.2013.10.018

Miransari M (2017). Arbuscular mycorrhizal fungi and heavy metal tolerance in plants. In: Wu QS (Ed). Arbuscular Mycorrhizas and Stress Tolerance of Plants. Singapore: Springer Nature, pp 174-161. https://doi.org/10.1007/978-3-319-68867-1_4

Nareshkumar A, Nagamallaiah GV, Pandurangaiah M, Kiranmai K, Amaranathareddy V, Lokesh U, ... Sudhakar C (2015). Pb-Stress induced oxidative stress caused alterations in antioxidant efficacy in two groundnut (Arachis hypogaea L.) cultivars. Agricultural Sciences 6:1283-1297. https://doi.org/10.4236/as.2015.610123

Nas FS, Ali M (2018). The effect of lead on plants in terms of growing and biochemical parameters: a review. MOJ Ecology \& Environmental Sciences 3(4):265-268.

Neagoe A, Stancu P, Nicoara A, Onete M, Bodescu F, Gheorghe R, Iordache V (2014). Effects of arbuscular mycorrhizal fungi on Agrostis capillaris grown on amended mine tailing substrate at pot, lysimeter, and field plot scales. Environmental Science and Pollution Research 21:6859-6876. https://doi.org/10.1007/s11356-013-1908-2

Pirbalouti AG, Bistghani ZE, Malekpoor F (2015). An overview on genus Thymus. Journal of Herbal Drugs 6(2):93-100. Polle A, Otter T, Seifert F (1994). Apoplastic peroxidase and lignification in needles of Norway Spruce Picea abies L. Plant Physiology 106:53-60. https://doi.org/10.1104/pp.106.1.53

Punamiya P, Datta R, Sarkar D, Barber S, Patel M, Da P (2010). Symbiotic role of Glomus mosseae in phytoextraction of lead in vetiver grass Chrysopogon zizanioides L. Journal of Hazardous Materials 177:465-474. https://doi.org/10.1016/j. jhazmat.2009.12.056

Rahimzadeh MR, Rahimzadeh MR, Kazemi S, Moghadamnia AA (2017). Cadmium toxicity and treatment: An update. Caspian Journal Internal Medicine 8(3):135-145. https://doi.org/10.22088/cjim.8.3.135

Rasheed R, Ashraf MA, Kamran S, Iqbal M, Hussain I (2018). Menadione sodium bisulphite mediated growth, secondary metabolism, nutrient uptake and oxidative defense in okra (Abelmoschus esculentus Moench) under cadmium stress. Journal of Hazardous Materials 360:604-614. https://doi.org/10.1016/j.jhazmat.2018.08.043

Ruiz E, Alonso-Azcárate J, Rodríguez L (2011). Lum bricus terrestris L. activity increases the availability of metals and their accumulation in maize and barley. Environmental Pollution 159:722-728. https://doi.org/10.1016/j.envpol.2010.11.032

Sairam RK (1994). Effect of homobrassinolide application on metabolism and grain yield under irrigated and moisture stress conditions of two wheat varieties. Plant Growth Regulation 14:173-181. https://doi.org/10.1007/BF00025220 
Shekoofeh E, Sepideh H, Roya R (2012). Role of mycorrhizal fungi and salicylic acid in salinity tolerance of Ocimum basilicum resistance to salinity. African Journal of Biotechnology 11(9):2223-2235. https://doi.org/10.5897/AJB11.1672

Siddhu G, Ali, MA (2012). Effect of cadmium on growth and metabolism of Phaseolus mungo. Journal of Environmental Biology 33(2):173-179.

Song L, Chen J, Islam E, Ying W, Wu J, Ye Z, ... Liu D (2016). Cadmium-induced oxidative stress response of antioxidants and detection of intracellular cadmium in organs of moso bamboo (Phyllostachys pubescens) seedlings. Chemosphere 153:107-114. https://doi.org/10.1016/j.chemosphere.2016.02.062

Song X, Yue X, Chen W, Jiang H, Han Y, Li X (2019). Detection of cadmium risk to the photosynthetic performance of Hybrid pennisetum. Frontiers in Plant Science 10:798-806. https://doi.org/10.3389/fpls.2019.00798

Tan SY, Jiang Q, Zhuo F, Liu H, Wang YT, Li SS, ... Jing YX (2015). Effect of inoculation with Glomus versiforme on cadmium accumulation, antioxidant activities and phytochelatins of Solanum photeinocarpum. PLoS One 10:116.

Usman K, Al-ghouti A, Abu-Dieyeh MH (2019). The assessment of cadmium, chromium, copper, and nickel tolerance and bioaccumulation by shrub plant Tetraena qataranse. Scientific Reports 9:5658. https://doi.org/10.1038/s41598-019-42029-9

Vasiljeva S, Smirnova G, Basova N, Babarykin D (2018). Cadmium-induced oxidative damage and protective action of fractioned red beet (Beta vulgaris) root juice in chickens. Agronomy Research 16:1517-1526. https://doi.org/10.15159/AR.18.117

Whitfield LAJ, Richards DL (2004). Rimmer. Relationships between soil heavy metal concentration and mycorrhizal colonisation in Thymus polytrichus in northern England. Mycorrhiza Journal 14(1):55-62. https://doi.org/10.1007/s00572-003-0268-Z

Wu QS, Xia RX (2006). Arbuscular mycorrhizal fungi influence growth, osmotic adjustment and photosynthesis of citrus under well-watered and water stress conditions. Journal of Plant Physiology 163:417-425. https://doi.org/10.1016/j.jplph.2005.04.024

Wuana RA, Okieimen FE (2011). Heavy metals in contaminated soils: a review of sources, chemistry, risks and best available strategies for remediation. International Scholarly Research Notices https://doi.org/10.5402/2011/402647

Yang Y, Liang Y, Han X, Chiu TY, Ghosh A, Chen H, Tang M (2016). The roles of arbuscular mycorrhizal fungi (AMF) in phytoremediation and tree-herb interactions in $\mathrm{Pb}$ contaminated soil. Scientific Reports 6:20469. https://doi.org/10.1038/srep20469

Yao Q, Yang R, Long L, Zhu HH (2014). Phosphate application enhances the resistance of arbuscular mycorrhizae in clover plants to cadmium via polyphosphate accumulation in fungal hyphae. Environmental and Experimental Botany 108:63-70. https://doi.org/10.1016/j.envexpbot.2013.11.007

Yemm EW, Folkes BF (1953). The estimation of carbohydrates in plant extracts by anthrone. Biochemistry Journal 55:700-701.

Yooyongwech S, Phaukinsang N, Cha-um S, Supaibulwatana K (2013). Arbuscular mycorrhiza improved growth performance in Macadamia tetraphylla L. grown under water deficit stress involves soluble sugar and proline accumulation. Plant Growth Regulation 69:285-293. https://doi.org/10.1007/s10725-012-9771-6

Zhang Y, Hu J, Bai J, Wang J, Yin R, Wang J, Lin X (2018). Arbuscular mycorrhizal fungi alleviate the heavy metal toxicity on sunflower (Helianthus annuus L.) plants cultivated on a heavily contaminated field soil at a WEEE-recycling site. Science of the Total Environment 629:282-290. https://doi.org/10.1016/j.scitotenv.2018.01.331

Zhao Y (2011). Cadmium accumulation and antioxidative defenses in leaves of Triticum aestivum L. and Zea mays L. African Journal of Biotechnology 10:2936-2943. https://doi.org/10.5897/AJB10.1230

Zou YN, Srivastava AK, Wu QS, Huang YM (2014). Increased tolerance of trifoliate orange (Poncirus trifoliata) seedlings to waterlogging after inoculation with arbuscular mycorrhizal fungi. Journal of Animal and Plant Sciences 24:1415-1420. 
OPEN ACCESS

(c) (i)

The journal offers free, immediate, and unrestricted access to peer-reviewed research and scholarly work. Users are allowed to read, download, copy, distribute, print, search, or link to the full texts of the articles, or use them for any other lawful purpose, without asking prior permission from the publisher or the author.

License - Articles published in Notulae Botanicae Horti Agrobotanici Cluj-Napoca are Open-Access, distributed under the terms and conditions of the Creative Commons Attribution (CC BY 4.0) License.

(C) Articles by the authors; UASVM, Cluj-Napoca, Romania. The journal allows the author(s) to hold the copyright/to retain publishing rights without restriction. 